\title{
Struktur Modal: Ditinjau dari Karakteristik Perusahaan yang Terdaftar di Jakarta Islamic Index 70 (JII70)
}

\author{
Bayu Tri Cahya $^{1}$, Siti Nafiah ${ }^{2}$, Suparwi ${ }^{3}$, Danang Kurniawan ${ }^{4}$, \\ IAIN Kudus ${ }^{1}$, IAIN Kudus ${ }^{2}$, IAIN Kudus ${ }^{3}$, IAIN Kudus ${ }^{4}$ \\ cahya380@gmail.com ${ }^{1}$, sitinafiah581@gmail.com ${ }^{2}$, parwiarif@gmail.com ${ }^{3}$, \\ kangkaji95@yahoo.com ${ }^{4}$
}

\begin{abstract}
Capital structure is a combination of long-term debt and the company's own capital in the form of retained earnings and the issuance of shares. This study aims to determine the effect of size, asset structure, and profitability on the capital structure of companies registered in the Jakarta Islamic Index 70. Jakarta Islamic Index 70 (JII70) is a sharia stocks index that was just launched in 2018. This research design is quantitative. The population in this study is companies listed on the Jakarta Islamic Index 70 during the 2018 period. The sample in this study was 51 company stocks. The techniques in this study are classic assumptions and multiple linear regression analysis. The results of this study indicate that the Asset Structure affects the capital structure. While profitability and size do not affect capital structure.
\end{abstract}

Keywords: Capital Structure, Company Characteristics, Jakarta Islamic Index 70

\section{Abstrak}

Struktur modal merupakan perpaduan antara hutang jangka panjang dan modal sendiri perusahaan yang berupa laba ditahan dan penerbitan saham. Penelitian ini bertujuan untuk mengetahui pengaruh size, struktur aktiva, dan profitabilitas terhadap struktur modal perusahaan yang terdaftar di Jakarta Islamic Index 70. Jakarta Islamic Index 70 (JII70) merupakan index saham syariah yang baru diluncurkan pada tahun 2018. Desain penelitian adalah kuantitatif. Populasi dalam penelitian ini adalah perusahaan yang terdaftar di Jakarta Islamic Index 70 selama periode tahun 2018. Sampel dalam penelitian ini sebanyak 51 saham perusahaan. Teknik dalam penelitian ini adalah asumsi klasik dan analisis regresi linear berganda. Hasil penelitian ini menunjukkan bahwa Struktur Aktiva berpengaruh terhadap struktur modal. Sedangkan Profitabilitas dan Size tidak berpengaruh terhadap struktur modal.

Kata Kunci: Struktur Modal, Karakteristik Perusahaan, Jakarta Islamic Index 70.

\section{PENDAHULUAN}

Setiap perusahaan dalam menjalankan operasional perusahaanya membutuhkan investasi dengan kebutuhan dana yang besar agar mampu menghasilkan produk-produk yang berkualitas tinggi, sehingga tetap unggul dan dapat bertahan di dalam persaingan bisnis. Di sisi lain, keterbatasan dana menjadi salah satu faktor penghambat besar (Fadhlillah et al.,2016 : 3140). Untuk memenuhi dana tersebut perusahaan biasanya menggunakan 
dua alternatif pendanaan yang bersumber dari dana internal dan dana eksternal. Sumber dana internal adalah dana yang bersumber dari laba ditahan, sedangkan dana eksternal bersumber dari hutang perusahaan (Dwilestari, 2010 : 153-154).

Struktur modal merupakan pembelajaran permanen dari perusahaan yang mencerminkan perbandingan atau perimbangan antara hutang jangka panjang perusahaan dengan modal sendiri perusahaan yang berupa laba ditahan dan penerbitan saham (Deviani dan Sudjarni, 2018 : 1223-1224). Perusahaan dapat dikatakan baik dalam bidang permodalannya apabila sebagian besar modal perusahaan yang digunakan untuk investasi maupun operasional berasal dari dana internal. Namun, dengan keterbatasan dana yang dimiliki, maka perusahaan mencari alternatif pendanaan yang berasal dari dana eksternal (Syamsiah, 2014 : 138).

Bertitik tolak dari pemaparan diatas peneliti ini melihat struktur modal ditinjau dari karakteristik perusahaan pada Jakarta Islamic Index 70 (JII70). JII70 adalah indeks saham syariah yang diluncurkan BEI pada tanggal 17 Mei 2018. Konstituen JII70 terdiri dari 70 saham syariah paling likuid yang tercatat di BEI. Sama seperti ISSI, review saham syariah yang menjadi konstituen JII dilakukan sebanyak dua kali dalam setahun, Mei dan November mengikuti jadwal review DES oleh OJK. JII70 berbeda dengan Jakarta Islamic Index (JII) sebelumnya yang diterbitkan tanggal 3 Juli 2000 yang terdiri dari 30 saham yang terpilih dari saham yang sesuai dengan syariah Islam. JII70 merupakan indeks atas 70 saham syariah yang memiliki kapitalisasi pasar dan likuiditas transaksi tinggi ( BEI, https://www.idx.co.id/idx-syariah/indeks-saham-syariah/ diakses pada 24 Februari, 2019).

\section{LITERATURE REVIEW}

\section{Teori Sinyal (Signaling Theory)}

Eungene Brigham dan Houston menjelaskan sinyal adalah tindakan yang diambil oleh manajer suatu perusahaan untuk memberikan pertunjuk kepada investor tentang bagaimana menilai prospek perusahaan. Sinyal ini berupa informasi mengenai apa yang sudah dilakukan oleh manajemen untuk mewujudkan keinginan pemilik perusahaan. Informasi yang diberikan oleh perusahaan merupakan hal yang penting dan berpengaruh terhadap keputusan investasi pihak diluar perusahaan. Salah satunya bagi investor dan pelaku bisnis, karena informasi pada hakekatnya memaparkan keterangan, catatan atau gambaran, baik untuk keadaan masa lalu, saat ini maupun masa yang akan datang bagi kelangsungan hidup perusahaan dan bagaimana efeknya pada perusahaan (Brigham dan Houston, Yulianto, 2011 : 186).

\section{Laporan Keuangan}

Laporan keuangan adalah catatan informasi keuangan suatu perusahaan pada suatu periode akuntansi yang dapat digunakan untuk menggambarkan kinerja perusahaan. Laporan keuangan merupakan bagian dari proses 
pelaporan keuangan. Kondisi keuangan suatu perusahaan dapat diketahui dari laporan keuangan perusahaannya (Riswan, 2014 : 2).

Secara umum ada lima jenis laporan keuangan yang biasa disusun perusahaan, diantaranya : Neraca, laporan laba rugi, Laporan perubahan modal, Laporan arus kas, Laporan catatan atas laporan keuangan (Kasmir, $2015: 28$ ).

\section{Struktur Modal}

Struktur modal merupakan perimbangan antara jumlah hutang jangka pendek bersifat permanen, hutang jangka panjang, saham preferen dan saham biasa. Struktur modal adalah perbandingan antara modal asing atau jumlah hutang dengan modal sendiri (Musthafa, 2017 : 85).

Struktur modal diukur dengan menggunakan rasio strktur modal yang disebut dengan leverage rasio. Perhitungan leverage rasio menunjukkan presentase modal sendiri yang dijadikan jaminan hutang jangka panjang yang dihitung dengan membandingkan antara hutang jangka panjang dengan modal sendiri (Nuswandari, 2013 : 94). Secara umum struktur modal dibagi menjadi dua bagian, yaitu : Struktur modal hutang dan Struktur modal sendiri (Dwilestari, 2010 : 155).

\section{Pengembangan Hipotesis}

\section{Pengaruh Size terhadap Struktur Modal}

Pada penelitian Angrita Denziana, dan Eilien Delicia Yunggo pada tahun 2017, menyatakan bahwa size (ukuran perusahaan) berpengaruh positif terhadap struktur modal (Denziana dan Delicia, 2017 : 24-25). Hasil yang sama juga ditemukan oleh Muhammad Nur Fadhlillah, Norita, dan Dewa Putra Krisna Mahardika pada tahun 2016 (Fadhlillah et al.,2016 : 8). Berdasarkan penjelasan dan hasil dari penelitian-penelitian terdahulu, maka dapat dirumuskan hipotesisnya sebagai berikut:

\section{H1: Size berpengaruh positif terhadap Struktur Modal}

\section{Pengaruh Struktur Aktiva terhadap Struktur Modal}

Pada penelitin yang dilakukan Joni dan Lina pada tahun 2010, menyatakan bahwa struktur aktiva berpengaruh positif terhadap struktur modal (Joni dan Lina , 2010). Hasil serupa juga ditemukan oleh Angrita Denziana, dan Eilien Delicia Yunggo pada tahun 2017 (Denziana dan Delicia, 2017 : 64-65). Berdasarkan penjelasan dan hasil dari penelitian-penelitian terdahulu, maka dapat dirumuskan hipotesisnya sebagai berikut:

\section{H2: Struktur aktiva berpengaruh positif terhadap Struktur Modal}

\section{Pengaruh Profitabilitas terhadap Struktur Modal}

Pada penelitin yang dilakukan Riski Ayu Pratiwi Batubara, Topowijoyo, dan Zahroh Z.A menyatakan bahwa profitabilitas berpengaruh terhadap struktur modal (Batubara et al.,2017 : 7). Hasil serupa juga ditemukan oleh Bram Hadianto,dan Christian Tayama pada tahun 2010 (Hadianto dan Tayama, 2010 : 35). Berdasarkan penjelasan dan hasil dari penelitian-penelitian terdahulu, maka dapat dirumuskan hipotesisnya sebagai berikut:

H3: Profitabilitas berpengaruh terhadap Struktur Modal 


\section{Kerangka Berfikir}

Berdasarkan landasan teori dan penelitian terdahulu yang sudah dijelaskan di atas, maka penelitian ini dapat digambarkan dalam kerangka berfikir sebagai berikut:

\section{Gambar 1 \\ Kerangka Berfikir}

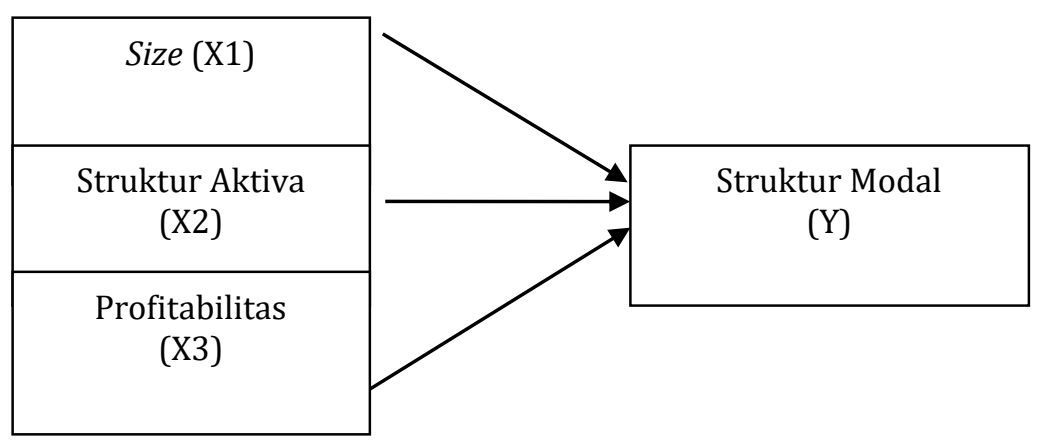

\section{METODE PENELITIAN}

\section{Jenis dan Pendekatan Penelitian}

Penelitian ini termasuk jenis metode penelitian kuantitatif adalah suatu metode penelitian yang digunakan untuk meneliti pada populasi atau sampel tertentu, pengumpulan data menggunakan instrumen penelitian, analisis data bersifat kuantitatif yang bertujuan untuk menguji hipotesis yang telah ditetapkan (Sugiyono, 2013: 8). Penelitian kuantitatif disini menggunakan data sekunder. Pedekatan kuantitatif yang digunakan disini menganalisis hubungan antara variabel-variabel dengan menggunakan teori yang objektif, serta menggunakan sampel dalam jumlah besar.

\section{Populasi dan Sampel}

Populasi adalah wilayah generalisasi yang terdiri atas objek atau subjek yang mempunyai kualitas dan karakteristik tertentu yang ditetapkan oleh peneliti untuk dipelajari dan kemudian ditarik kesimpulannya (Sugiyono, 2015 : 80). Populasi dalam penelitian ini adalah seluruh perusahaan yang tercatat dalam indeks Jakarta Islamic Index 70 (JII70) pada Bursa Efek Indonesia (BEI) yang aktif melapor dan mempublikasikan laporan keuangannya selama kurun waktu tahun 2018 yang berjumlah sebanyak 70 perusahaan, diperoleh dari website resmi Bursa Efek Indonesia (BEI) yaitu www.idx.co.id.

Sampel adalah suatu bagian dari populasi tertentu yang menjadi perhatian ( Suharyadi dan Purwanto, 2009 : 7). Pengambilan sampel sesuai dengan kualitas dan karakteristik dari populasi. Pengambilan sampel yang tidak sesuai dengan kualitas dan karakteristik dari populasi akan menyebabkan suatu peneltian tidak dapat dipercaya dan kesimpulannya akan bisa menjadi keliru (Sugiyono , 2014 : 68). Penarikan sampel dalam penelitian ini menggunakan purposive sampling yaitu penarikan sampel berdasarkan pertimbangan tertentu (Suharyadi dan Purwanto, 2009 : 17). 


\section{Identifikasi Variabel}

Variabel dalam penelitian ini adalah:

1. Variabel Dependen

Variabel terikat merupakan variabel yang dipengaruhi atau menjadi akibat adanya variabel bebas ( Sugiyono, 2015 : 39). Variabel dependen dalam penelitian ini adalah struktur modal perusahaan yang diukur dengan menggunakan Debt to Equity Ratio (DER) merupakan rasio yang mengukur jumlah utang atau dana luar perusahaan terhadap modal sendiri. Rasio ini menggambarkan sejauh mana modal pemilik dapat menutupi hutang-hutang kepada pihak luar perusahaan ( Harahap, 2002 : $55)$.

2. Variabel Independen

Variabel bebas merupakan variabel yang mempengaruhi atau yang menjadi sebab perubahan atau timbulnya variabel terikat (Sugiyono, 2015 : 39). Variabel-variabel independen dalam penelitian ini adalah sebagai berikut:

a. Size (Ukuran Perusahaan)

Size (ukuran perusahaan) merupakan nilai yang menggambarkan besarnya suatu perusahaan yang diukur berdasarkan besarnya asset yang dimiliki oleh perusahaan. Pada penelitian ini, ukuran perusahaan diproksikan dengan menggunakan natural logaritma (ln) dari total asset (Sitanggang, $2013: 76$ ).

b. Struktur Aktiva

Struktur aktiva adalah perbandingan antara aktiva tetap dengan total aktiva yang dimiliki oleh perusahaan. Struktur aktiva dalam penelitian ini diukur dengan rasio Fixed Assets to Total Assets (FTA) ( Dwilestari, 2010 : 160).

c. Profitabilitas

Profitabilitas merupakan rasio untuk menilai kemampuan perusahaan dalam mencari keuntungan. Rasio ini juga memberikan ukuran tingkat efektivitas manajemen suatu perusahaan. Hal ini dapat dilihat dari jumlah laba yang diperoleh dari penjualan dan pendapatan investasi. Profitabilitas dalam penelitian ini diukur dengan menggunakan Return on Total Assets (ROA). ROA merupakan rasio yang menunjukkan hasil (return) atas jumlah aktiva yang digunakan dalam perusahaan (Kasmir, 2006 : 201-202).

\section{Teknik Pengumpulan Data}

Data penelitian ini dikumpulkan melalui buku-buku, jurnal-jurnal riset, dan literatur lain yang mendukung dalam penelitian ini. Teknik yang digunakan dalam pengumpulan data yang digunakan dalam penelitian ini adalah dokumentasi, yaitu dengan cara mengumpulkan bahan - bahan dan literatur yang menunjang dalam penyusunan penelitian.

Data dalam penelitian ini berupa laporan keuangan tahunan lengkap dengan laporan auditor yang diperoleh dari website perusahaan yang bersangkutan 
yang di publikasikan di Bursa Efek Indonesia dan dari situs-situs perusahaan yang terdaftar di Jakarta Islamic Index 70 (JII70), selama periode tahun 2018.

\section{HASIL PENELITIAN DAN PEMBAHASAN \\ Deskripsi dan Perhitungan Sampel}

Dari website resmi Bursa Efek Indonesia (BEI) www.idx.co.id diperoleh populasi dalam penelitian ini yaitu sebanyak 70 perusahaan. Berdasarkan dari pengumpulan data sesuai kriteria yang ditentukan diperoleh sampel sebanyak 51 perusahaan yang digunakan sebagai sampel dalam penelitian ini. Berikut adalah perhitungan sampel perusahaan dan daftar nama-nama perusahaan yang menjadi sampel dalam penelitian ini dapat dilihat pada tabel berikut:

\section{Tabel 1}

Perhitungan Sampel

\begin{tabular}{c|l|c}
\hline No & \multicolumn{1}{|c|}{ Kriteria } & Jumlah \\
\hline 1 & $\begin{array}{l}\text { Perusahaan yang terdaftar di Jakarta Islamic } \\
\text { Index 70 (JII70) tahun 2018 }\end{array}$ & 70 \\
\hline 2 & Data outlier & 19 \\
\hline & Sampel Akhir Penelitian & 51
\end{tabular}

Sumber: Hasil Olah Peneliti

\section{Uji Asumsi Klasik}

Dalam penelitian kali ini ada 3 uji yang akan diteliti, diantaranya uji normalitas, uji multikolonearitas, dan uji heteroskedastisitas. Hasil dari uji asumsi klasik tersebut disajikan dalam tabel berikut:

Tabel 2

Hasil Uji Asumsi Klasik

\begin{tabular}{|c|c|}
\hline Uji Asumsi Klasik & Keterangan \\
\hline $\begin{array}{l}\text { Uji Normalitas } \\
\text { Asymp. Sig }\end{array}$ & $\begin{array}{l}0,318 \\
\text { Data yang digunakan normal karena nilai } \\
\text { signifikan lebih dari } 0,05\end{array}$ \\
\hline $\begin{array}{l}\text { Uji } \\
\text { Multikolonearitas } \\
\quad \text { Tolerance }\end{array}$ & $\begin{array}{lc}\text { Size } 0,952 & \\
\text { Struktur Aktiva } & 0,941 \\
\text { Profitabilitas } & 0,963\end{array}$ \\
\hline VIF & $\begin{array}{lc}\text { Size } & 1,050 \\
\text { Struktur Aktiva } & 1,062 \\
\text { Profitabilitas } & 1,039 \\
& \\
\text { Tidak terjadi multikolinearitas karena tidak } \\
\text { ada variabel independen yang memiliki }\end{array}$ \\
\hline
\end{tabular}




\begin{tabular}{l|lc} 
& $\begin{array}{l}\text { nilai tolerance kurang dari 0,10 dan tidak } \\
\text { ada variabel yang memiliki nilai VIF lebih } \\
\text { dari 10. }\end{array}$ \\
\hline $\mathbf{U j i}$ & Size & 0,631 \\
Heteroskedastisitas & Struktur Aktiva 0,759 \\
& Profitabilitas & 0,871 \\
& & \\
& Tidak terjadi heteroskedastisitas, karena \\
number: diolah oleh peneliti
\end{tabular}

\section{Hasil Analisis Data}

Pada penelitian ini ada 4 uji yang dilakukan, diantaranya adalah uji koefisien determinan (adjusted $\mathrm{R}^{2}$ ), uji Signifikasi Simultan F (Uji f), Uji Signifikasi Parsial (Uji t), dan Analisis Regresi Linear Berganda. Adapun hasil dari analisis data dapat dilihat dari tabel dibawah ini:

Tabel 3

Hasil Uji Analisis Data

\begin{tabular}{|c|c|}
\hline Analisis Data & Keterangan \\
\hline $\begin{array}{l}\text { Uji Koefisien Determinasi } \\
\text { (Adjusted } R^{2} \text { ) }\end{array}$ & 0,204 \\
\hline $\begin{array}{l}\text { Uji Signifikasi Simultan F } \\
\text { F } \\
\text { Sig }\end{array}$ & $\begin{array}{l}5,279 \\
0,003\end{array}$ \\
\hline $\begin{array}{l}\text { Uji Signifikansi Parsial (Uji- } \\
\text { T) } \\
\text { Koefisien kesalahan } \\
\text { standar }\end{array}$ & $\begin{array}{lc}\text { Konstanta } & -3,885 \\
\text { Size } & 0,769 \\
\text { Struktur Aktiva } & 0,087 \\
\text { Profitabilitas } & -0,217\end{array}$ \\
\hline $\mathrm{t}$ & $\begin{array}{lc}\text { Size } & 2,922 \\
\text { Struktur Aktiva } & 0,846 \\
\text { Profitabilitas } & -1,751\end{array}$ \\
\hline Sig. & $\begin{array}{lc}\text { Size } & 0,705 \\
\text { Struktur Aktiva } & 0,026 \\
\text { Profitabilitas } & 0,086\end{array}$ \\
\hline
\end{tabular}

Dari data diatas besarnya adjusted $\mathrm{R}^{2}$ adalah 0,204 , hal ini berarti $20,4 \%$ variasi Struktur Modal dapat dijelaskan oleh variasi ke tiga variabel independent Size, Struktur Aktiva, dan Profitabilitas. Sedangkan sisanya $(100 \%-20,4 \%=79,6 \%)$ dipengaruhi oleh variabel-variabel yang lain di luar variabel yang diteliti. 
Sedangkan hasil perhitungan statistik uji F diperoleh nilai sig. $(0,003)<\propto=$ 0,05 maka model analisis regresi adalah signifikan. Hal ini berarti $\mathrm{H}_{0}$ di tolak $\mathrm{H}_{1}$ diterima sehingga dapat disimpulkan bahwa variabel terikat Struktur Modal (Y) secara simultan di pengaruhi oleh variabel bebas Size (X1), Struktur Aktiva (X2), dan Profitabilitas (X3).

Berdasarkan hasil perhitungan diatas, dapat dijelaskan bahwa penelitian ini bertujuan untuk menguji pengaruh Size, Struktur Aktiva, dan Profitabilitas terhadap Struktur Modal perusahaan yang terdaftar di Jakarta Islamic Index 70 (JII70) periode tahun 2018. Berdasarkan hasil analisis diatas, maka hasil penelitiannya adalah sebagai berikut:

\section{Pengaruh Size Terhadap Struktur Modal}

Hasil penelitian menunjukkan bahwa Size tidak berpengaruh terhadap Struktur Modal, hal ini dilihat dari hasil pengujian satu sisi yang digunakan menggunakan tingkat signifikan sebesar $\propto=0,05$ dan dengan derajat kebebasan $d f=(N-k-1)=51-3-1=47$ diperoleh t tabel $\pm 1,6779$. Kaidah pengambilan keputusannya adalah dikatakan tidak berpengaruh jika nilai t-hitung lebih besar dari t-tabel. Hasil perhitungan diperoleh nilai thitung sebesar 2,922. Dengan demikian t-hitung lebih besar dari t-tabel $(2,922<1,6779)$, sehingga $\mathbf{H 1}$ ditolak. Artinya tidak terdapat pengaruh Size terhadap Struktur Modal Perusahaan yang Terdaftar di Jakarta Islamic Index 70 (JII70) periode tahun 2018. Hasil penelitian menunjukkan bahwa variabel Size memiliki nilai koefisien signifikansi sebesar 0,705 yang lebih besar dari 0,05, sehingga dapat disimpulkan bahwa tidak terdapat pengaruh Size terhadap Struktur Modal.

Hasil penelitian ini sesuai dengan penelitian yang dilakukan oleh Ida Bagus Made Dwija Bhawa dan Made Rusman Dewi S. pada tahun 2015 menunjukkan bahwa variabel ukuran perusahaan berpengaruh negatif tidak signifikan terhadap struktur modal. Hal ini dikarenakan kesalahan dalam pengambilan keputusan pendanaan, manajemen perusahaan tidak mampu mengelola struktur modal perusahaan dengan optimal (Bhawa, dan Desi, 2015 : 1961). Ukuran perusahaan menggambarkan besar kecilnya suatu perusahaan. Semakin besar keuntungan yang diperoleh perusahaan maka semakin besar pula kemampuan perusahaan dalam membiayai operasionalnya, sehingga semakin kecil hutang yang diperlukan oleh perusahaan. Dalam suatu perusahaan perlu diperhatikan pengelolaan struktur modal, sehingga perusahaan dapat berjalan serta laba yang dihasilkan dapat optimal.

\section{Pengaruh Struktur Aktiva terhadap Struktur Modal}

Hasil penelitian menunjukkan bahwa Struktur Aktiva berpengaruh terhadap Struktur Modal, hal ini dapat dilihat dari hasil pengujian satu sisi yang digunakan menggunakan tingkat signifikan sebesar $\propto=0,05$ dan dengan derajat kebebasan $d f=(N-k-1)=51-3-1=47$ diperoleh t-tabel $\pm 1,6779$. Kaidah pengambilan keputusannya adalah dikatakan berpengaruh 
jika nilai t-hitung lebih kecil dari t-tabel. Hasil perhitungan diperoleh nilai thitung sebesar 0,846. Dengan demikian t-hitunglebih kecil dari t-tabel $(0,846>1,6779)$, sehingga $\mathbf{H 2}$ diterima. Artinya terdapat pengaruh Struktur Aktiva terhadapStruktur Modal Perusahaan yang terdaftar di Jakarta Islamic Index 70 (JII70) periode tahun 2018.Hasil penelitian menunjukkan bahwa variabel Struktur Aktiva memiliki nilai koefisien signifikansi sebesar 0,026 yang lebih kecil dari 0,05, sehingga dapat disimpulkan bahwa terdapat pengaruh Struktur Aktiva terhadap Struktur Modal.

Hasil penelitian ini sesuai dengan penelitian yang dilakukan oleh Gilda Maulina, Ferina Nurlaily, dan Nila Firdausi pada tahun 2018 menunjukkan bahwa variabel struktur aktiva berpengaruh terhadap struktur modal. Hal ini dikarenakan struktur aktiva dapat digunakan untuk menentukan seberapa besar utang yang dapat diambil dan hal ini akan terpengaruh terhadap penentuan besarnya struktur modal (Maulina et al.,2018 : 163). Struktur aktiva menggambarkan tentang jumlah kekayaan perusahaan yang dapat dijadikan jaminan hutang. Ketika perusahaan kesulitan dalam pendanaanya dapat menjual aset yang dimiliki untuk dijadikan jaminan hutang yang nantinya digunakan untuk operasional perusahaan, sehingga perusahaan dapat berjalan dengan baik. Dengan mengatahui struktur aktiva perusahaan dapat menentukan seberapa besar struktur modal yang diperlukan.

\section{Pengaruh Profitabilitas terhadap Struktur Modal}

Hasil penelitian menunjukkan bahwa Profitabilitas tidak berpengaruh terhadap Struktur Modal, hal ini dapat dilihat dari hasi pengujian satu sisi yang digunakan menggunakan tingkat signifikan sebesar $\propto=0,05$ dan dengan derajat kebebasan $d f=(N-k-1)=51-3-1=47$ diperoleh ttabel $\pm 1,6779$. Kaidah pengambilan keputusannya adalah dikatakan tidak berpengaruh jika nilai t-hitung lebih kecil dari t-tabel. Hasil perhitungan diperoleh nilai t-hitung sebesar -1,751. Dengan demikian t-hitung lebih besar dari t-tabel $(-1751<1,6779)$, sehingga $\mathbf{H 3}$ ditolak. Artinya tidak terdapat pengaruh Profitabilitas terhadapStruktur Modal Perusahaan yang terdaftar di Jakarta Islamic Index 70 (JII70) periode tahun 2018. Hasil penelitian menunjukkan bahwa variabel Profitabilitas memiliki nilai koefisien signifikansi sebesar 0,086 yang lebih besar dari 0,05, sehingga dapat disimpulkan bahwa tidak terdapat pengaruh Profitabilitas.

Hasil penelitian ini sesuai dengan penelitian yang dilakukan oleh Lusia Insiroh pada tahun 2014 menunjukkan bahwa profitabilitas tidak berpengaruh terhadap struktur modal. Dengan meningkatnya profitabilitas perusahaan maka akan menurunkan hutang perusahaan sebagai akibat dari semakin tingginya aktivitas perusahaan yang menandakan adanya prospek dan peluang yang semakin bagus untuk terus meningkatkan pendapatan. Ketika aktivitas perusahaan semakin tinggi sehingga produknya mampu menembus pasar yang ditargetkan dan akan mendatangkan keuntungan yang semakin tinggi, sehingga perusahaan tidak perlu mengambil dana dari luar untuk membiayai operasionalnya (Insiroh, 2014 : 984). Semakin besar 
profitabilitas suatu perusahaan maka struktur modal semakin kecil dan sebaliknya jika semakin kecil profitabilitas yang dimiliki oleh suatu perusahaan maka semakin besar struktur modal yang diperlukan.

\section{SIMPULAN}

Berdasarkan hasil perhitungan statistik yang telah dilakukan, maka dapat diperoleh kesimpulan sebagai berikut:

1. Variabel Size tidak berpengaruh terhadap Struktur Modal Perusahaan yang Terdaftar di Jakarta Islamic Index 70 (JII70) periode tahun 2018.

2. Variabel Struktur Aktiva berpengaruh terhadap Struktur Modal Perusahaan yang terdaftar di Jakarta Islamic Index 70 (JII70) periode tahun 2018.

3. Variabel Profitabilitas tidak berpengaruh terhadap Struktur Modal Perusahaan yang terdaftar di Jakarta Islamic Index 70 (JII70) periode tahun 2018.

\section{DAFTAR PUSTAKA}

Tayama, Christian dan Hadianto, Bram. (2010). Pengaruh Risiko Sistematik, Struktur Aktiva, Profitabilitas, dan Jenis Perusahaan Terhadap Struktur Modal Emiten Sektor Pertambangan: Pengujian Hipotesis Static-Trade Off', Jurnal Akuntansi, 2, no.1.

Putra, Dewa., Fadhlillah, Muhammad Nur., dan Novita. (2016). Pengaruh Struktur Aktiva, Ukuran Perusahaan dan Profitabilitas Terhadap Struktur Modal (Studi Kasus Pada Perusahaan Sektor Properti dan Real Estate Yang Terdaftar di Bursa Efek Indonesia Tahun 2011-2015), Jurnal e-Proceeding of Management, 3, no.3.

Dwilestari, Anita. (2010). Pengaruh Struktur aktiva, Pertumbuhan, dan Likuiditas Terhadap Struktur Modal Perusahaan, Jurnal Riset Akuntansi dan Keuangan, 6, no.2.

Delicia, Eilien dan Denziana, Angrita. (2017). Pengaruh Profitabilitas, Struktur Aktiva, dan Ukuran Perusahaan Terhadap Struktur Modal Perusahaan pada Perusahaan Real Estate and Property yang Terdaftar di Bursa Efek Indonesia Tahun 2015, Jurnal Akuntansi \& Keuangan, 8, no.1.

Harahap, Sofyan Syafri. (2002). Analisa Kritis atas Laporan Keuangan, Jakarta: Raja Grafindo Persada.

Insiroh, Lusia. (2014). Pengaruh Profitabilitas, Ukuran Perusahaan, Pertumbuhan Aset, dan Struktur Aset terhadap Struktur Modal, Jurnal Ilmu Manajemen, 2, no.3.

Sitanggang, J.P. (2013). Manajemen Keuangan Perusahaan Lanjutan, Jakarta: Mitra Wacana Media.

Houston, Joel F. dan Brigham, Eungene F. (2011). Dasar-dasar Manajemen Keuangan, terj. Ali Akbar Yulianto, Jakarta: Salemba Empat. 
Kasmir. (2016). Analisis Laporan Keuangan, Jakarta: PT Raja Grafindo Persada.

Joni dan Lina. (2010). Faktor-faktor yang Mempengaruhi Struktur Modal, Jurnal Bisnis dan Akuntansi, 12, no.2.

Sudjarni, Luh Komang dan Deviani, Made Yunitri. (2018), Pengaruh Tingkat Pertumbuhan, Struktur Aktiva, Profitabilitas, dan Likuiditas terhadap Struktur Modal Perusahaan Pertambangan di BEI, E-Jurnal Manajemen Unud, 7, no.3.

Bhawa, Ida Bagus Made Dwija dan S., Made Rusmala Desi. (2015). Pengaruh Ukuran Perusahaan, Likuiditas, Profitabilitas, dan Risiko Bisnis terhadap Struktur Modal Perusahaan Farmasi, E-Jurnal Manajemen Unud, 4, no.7.

Musthafa. (2017). Manajemen Keuangan, Yogyakarta: CV Andi Offset.

Firdausi, Nila. (2018). Maulina, Gilda dan Nurlaily, Ferina., Pengaruh Faktorfaktor Penentu Struktur Modal (Studi pada Perusahaan Manufaktur yang Terdaftar di Bursa Efek Indonesia periode 2014-2016), Jurnal Administrasi Bisnis (JAB), 58, 1 Mei.

Nuswandari, Cahyani. (2013). Determinan Struktur Modal dalam Perspektif Pecking Order Theory dan Agency Theory, Jurnal Dinamika Akuntansi, Keuangan, dan Perbankan, 2, no.1.

PT Bursa Efek Indonesia, "Indeks Saham Syariah," diakses pada 24 Februari, 2019. https://www.idx.co.id/idx-syariah/indeks-saham-syariah/

Purwanto, dan Suharyadi. (2009). Statistika untuk Ekonomi dan Keuangan Modern Edisi ke dua, Yogyakarta: Salemba Empat.

Riswan. (2014). Analisis Laporan Keuangan Sebagai Dasar dalam Penilaian Kinerja Kuangan PT.Budi Satria Wahana Motor, Jurnal Akuntansi \& Keuangan, 5,no.1.

Sugiyono. (2013). Metode Penelitian Kuantitatif, Kualitatif dan R\&D, Bandung: Alfabeta.

Sugiyono. (2015). Metode Penelitian Pendidikan Pendekatan Kuantitatif, Kualitatif dan $R \& D$, Bandung: Alfabeta.

Sugiyono. (2014). Statistika Untuk Penelitian, Bandung: Alfabeta.

Syamsiah. (2014). Analisis Struktur Modal Perusahaan yang Terdaftar di Jakarta Islamic Index (JII) tahun 2009-2013, Jurnal Iqtishadia, 7, no.1.

Zahroh, Riski Ayu Pratiwi Batubara,dan Topowijoyo. (2017). Pengaruh Struktur Aktiva, Ukuran Perusahaan, dan Profitabilitas Terhadap Struktur Modal (Studi pada Perusahaan Makanan dan Minuman yang Terdaftar di Bursa Efek Indonesia Tahun 2012-2015), Jurnal Administrasi Bisnis (JAB), 50, no.4. 
Bayu Tri Cahya dkk.

Halaman ini sengaja dikosongkan 